This page intentionally left blank. 
This page intentionally left blank. 


\section{THE SAGA OF THE JÓMSVÍKINGS}




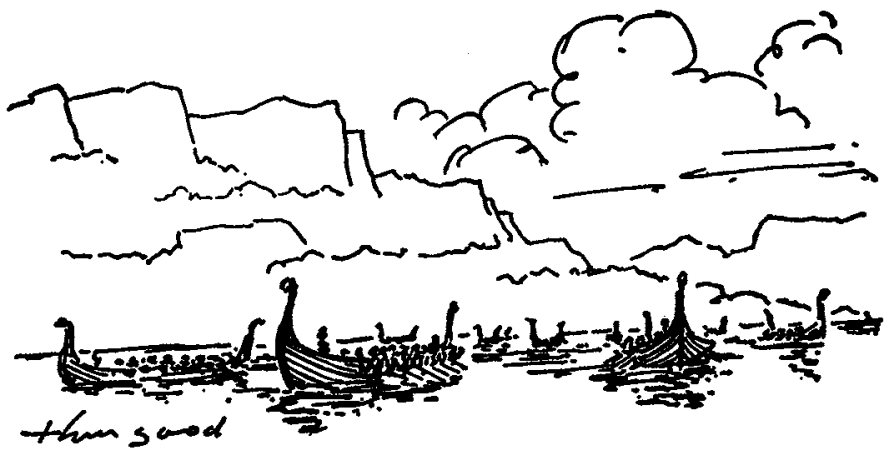




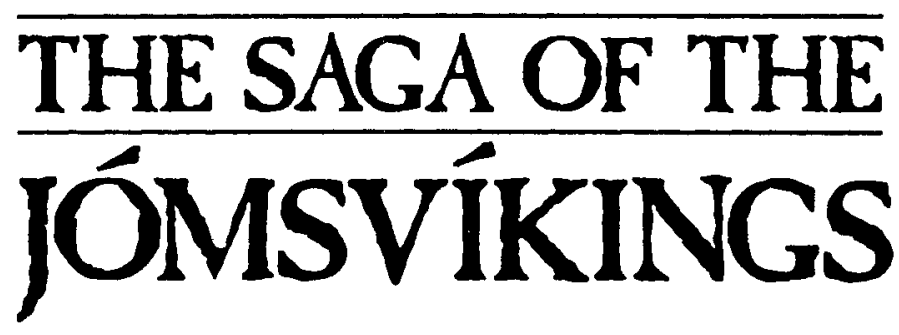

Translated from the Old Icelandic with Introduction and Notes by

\section{Lee M. Hollander}

Illustrated by Malcolm Thurgood

$\checkmark \checkmark$ UNIVERSITY OF TEXAS PRESS AUSTIN 
ISBN 978-0-292-77623-4

Library of Congress Catalog Card Number 54-7338

Copyright (ㅇ I955 by the University of Texas Press

All rights reserved

Printed in the United States of America

Eighth paperback printing, 20I I

Requests for permission to reproduce material from this work should be sent to Permissions, University of Texas Press, P. O. Box 7819, Austin, Texas 7871 3-7819. www.utexas.edu/utpress/about/bpermission.html

(6) The paper used in this book meets the minimum requirements of ANSI/NISO Z39.48-I992 (RI997) (Permanence of Paper). 
TO MY NORWEGLAN FRIENDS 
This page intentionally left blank. 